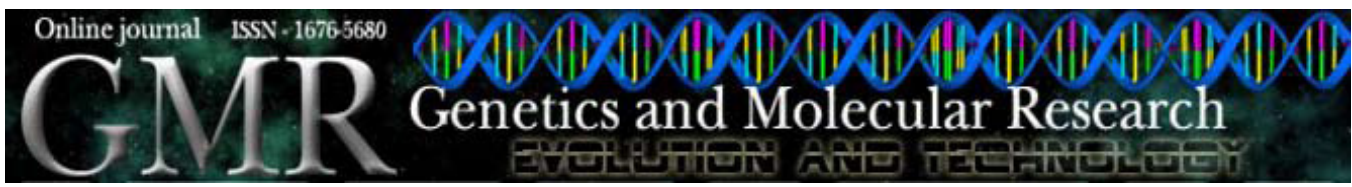

Short Communication

\title{
Isolation and characterization of 12 polymorphic microsatellite markers for the frog Pelophylax hubeiensis
}

J.-C. Yan, F.-H. Zhu and H.-L. Wu

Key Laboratory of Biotic Environment and Ecological Safety, Anhui Province, China

Key Laboratory for the Conservation and Utilization of Important Biological Resources, Anhui Province, China

Corresponding author: H.-L. Wu

E-mail: whlong@mail.ahnu.edu.cn

Genet. Mol. Res. 10 (1): 268-272 (2011)

Received October 6, 2010

Accepted January 5, 2010

Published February 15, 2011

DOI 10.4238/vol10-1gmr1003

ABSTRACT. Twelve polymorphic microsatellite loci were isolated from an $(\mathrm{AC})_{\mathrm{n}}$ - and (AG) -enriched DNA library for the endemic Chinese frog Pelophylax hubeiensis (Ranidae). The number of alleles per locus ranged from two to eight, with a mean of 5.17. The observed and expected heterozygosities ranged from 0.226 to 0.839 and from 0.204 to 0.826 , with means of 0.568 and 0.656 , respectively. No significant linkage disequilibrium was detected among these loci. However, two significant deviations from HWE were discovered at loci Pehu-11 and Pehu-12 (P < 0.05). MICRO-CHECKER tests showed that null alleles could be present at locus Pehu-12. These polymorphic microsatellite loci can be employed for exploring mating mechanisms, population genetic structure and other relevant genetic investigations of $P$. hubeiensis.

Key words: Pelophylax hubeiensis; Genetic marker; Microsatellite; Polymorphism 
Amphibian populations have been the focus of numerous studies that have contributed to our general understanding of ecological and evolutionary phenomena (Newman, 1988; Wilbur, 1997; McDiarmid and Altig, 1999). For example, amphibians are ideal for testing predictions about the relationship between reproductive strategy and sexual asymmetry in dispersal (Austin et al., 2003). Among the Pelophylax plancyi species complex, one species, P. chosenicus (Okada, 1931), occurs only on the Korean Peninsula, and the other three species, P. plancyi (Lataste, 1880), P. fukienensis (Pope, 1929) and P. hubeiensis (Fei and Ye, 1982), are endemic to China. $P$. hubeiensis was reported to be only distributed in Hubei and Anhui provinces. The most distinct difference between the species and the other species of the P. plancyi species complex is that the former shows the absence of the internal vocal sac in males (Fei and Ye, 1982). However, the species validity of $P$. hubeiensis was questioned by some molecular evidence (Liu et al., 2010). Therefore, to elucidate the systematic position of the species, new robust evidence, such as reproductive mechanism, etc., should be provided. Microsatellite markers have proved to be effective in exploring mating mechanisms and are widely applied in mammals, birds, reptiles, and amphibians (Austin et al., 2003; Foerster et al., 2003; Coulon et al., 2006; Uller and Olsson, 2008). Recently, Dai and Zhou (2009) developed a set of polymorphic microsatellite loci for P. plancyi, and all loci were found to be amplified successfully in the Pelophylax species. However, according to the authors' suggestions, it was uncertain whether 6 of 13 loci existed as null alleles. Furthermore, in our laboratory, some of the loci were found to be monomorphic in $P$. hubeiensis. In order to increase the number of effective microsatellite loci for determining the mating mechanism in P. hubeiensis, in the current study, a set of new polymorphic microsatellite loci were isolated.

Microsatellites were isolated from an enriched library constructed using a modified biotincapture method (Hamilton et al., 1999). Briefly, genomic DNA was extracted from muscle samples using a standard phenol-chloroform protocol (Sambrook and Russell, 2001). After about $4 \mu \mathrm{g}$ genomic DNA was digested with Sau3AI, DNA fragments ranging from 400 to $900 \mathrm{bp}$ were purified from a $1.5 \%$ agarose gel, using a gel extraction column kit (TaKaRa) and ligated to the linkers made by annealing equimolar amounts of Sau-L-A and Sau-L-B. The ligated DNA molecules were then hybridized to single-stranded 5-biotinylated $(\mathrm{AC})_{12}$ or $(\mathrm{AG})_{12}$ oligonucleotide probes and captured with streptavidin-coated beads (Roche). Microsatellite-enriched fragments were amplified by polymerase chain reaction (PCR) using Sau-L-A as the primer, and the double-stranded products were ligated to the plasmid pMD18-T vector (TaKaRa). The recombinant plasmid was transformed into DH5a competent cells. PCR using Sau-L-A and the oligonucleotides (AC) $)_{12}$ or (AG) $)_{12}$ as the primers was employed to identify the transformants. Clones that yielded two or more bands contained microsatellite fractions. In total, 198 positive clones were obtained, and 150 of them were selected and sequenced on an automated ABI 3700 DNA sequencer. Ninety-three primer pairs were designed according to the sequence flanking the repeat motifs using Primer Premier 5.0 (http://www.premierbiosoft.com/). Twenty-two sets of primers that gave consistent and specific PCR products were tested for allelic polymorphism. DNA from 31 samples (muscle or skin tissues), which were collected from Wuwei County in Anhui Province, was used as PCR templates to screen allelic polymorphism for each locus. PCR was carried out in a $15-\mu \mathrm{L}$ reaction mixture, including 20-30 ng template DNA, 0.8 U Taq DNA polymerase (TaKaRa), $1.5 \mu \mathrm{L} 10 \mathrm{X}$ PCR buffer (TaKaRa), $\mathrm{MgCl}_{2}$ (Table 1), $1.2 \mu \mathrm{L} 20 \mathrm{mM}$ dNTPs, $0.1 \mu \mathrm{L}$ BSA, and $0.3 \mu \mathrm{L} 10 \mathrm{mM}$ of the locusspecific primer. The PCR conditions were as follows: $95^{\circ} \mathrm{C}$ for $5 \mathrm{~min}$, followed by 30 cycles of 30 $\mathrm{s}$ at $95^{\circ} \mathrm{C}, 30 \mathrm{~s}$ at optimized annealing temperatures (Table 1), and $30 \mathrm{~s}$ at $72^{\circ} \mathrm{C}$, and a final extension at $72^{\circ} \mathrm{C}$ for $5 \mathrm{~min}$. 


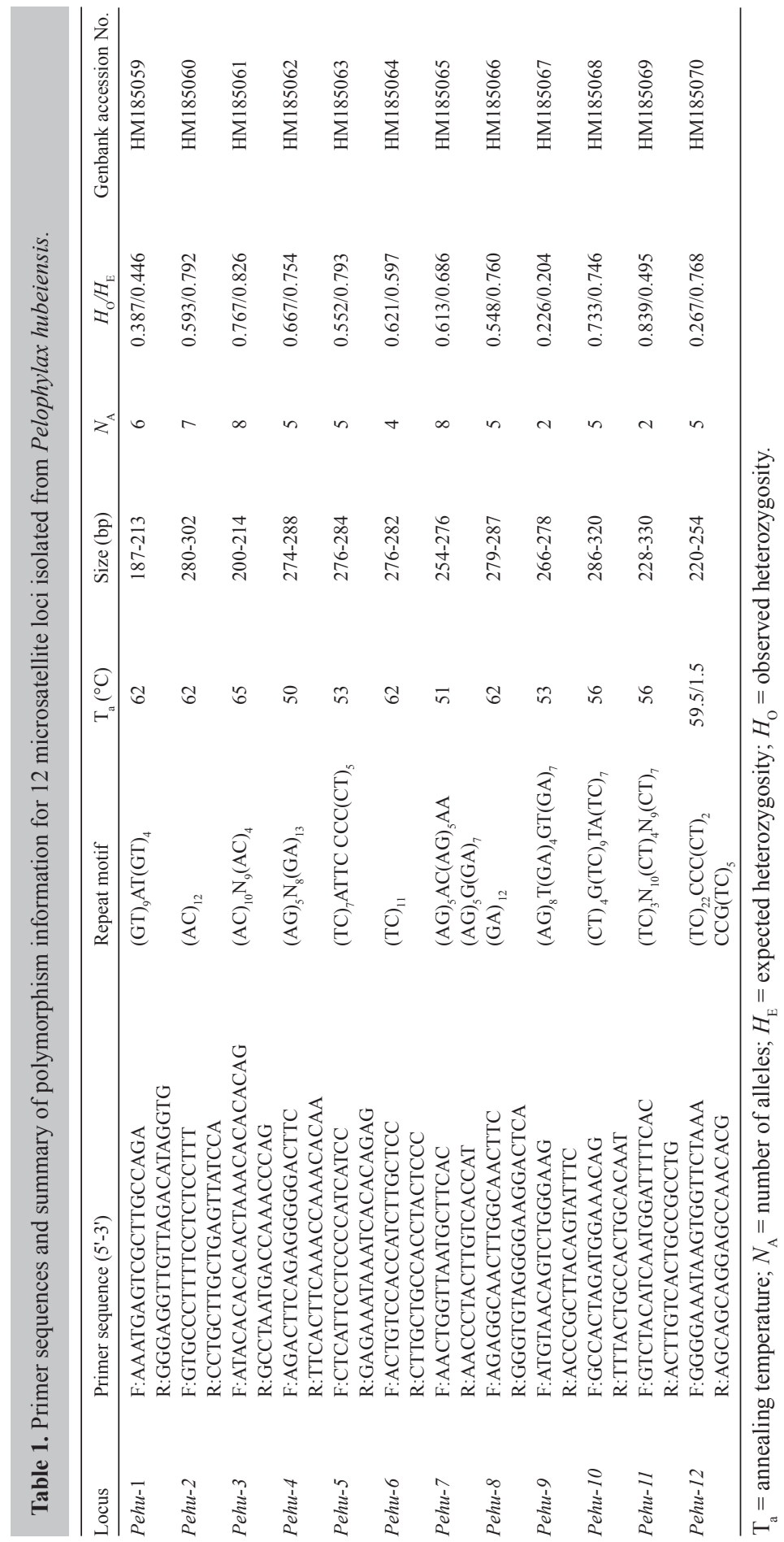


Polymorphism investigation was only conducted for those primer pairs giving correct and consistent specific products. Amplification products, loaded on $8.0 \%$ denaturing polyacrylamide gels, were analyzed on a Li-Cor 4200 automated DNA sequencer, with a size standard (50-350 bp, IRDye700 or IRD-800). Gel images were analyzed using the SAGAGT software.

The Genetix software (Belkhir et al., 1996) was used to determine the number of alleles $\left(N_{\mathrm{A}}\right)$ per locus, and observed $\left(H_{\mathrm{O}}\right)$ and expected $\left(H_{\mathrm{E}}\right)$ heterozygosities. Tests for significant deviation from Hardy-Weinberg equilibrium (HWE) and linkage disequilibrium were performed using Genepop version 4.0 (Raymond and Rousset, 1995). MICRO-CHECKER version 2.2.3 (van Oosterhout et al., 2004) was used to identify null alleles.

In total, 12 polymorphic microsatellite loci were isolated in this study. The number of alleles, PCR product size and heterozygosity of these loci are summarized in Table 1. A total of 62 alleles were identified from 31 samples of the species, and the number of alleles per locus ranged from two to eight with an average of 5.17. Two loci, Pehu-9 and Pehu11, contained only two alleles, respectively. The observed and expected heterozygosities ranged from 0.226 to 0.839 and 0.204 to 0.826 . Compared with the loci developed for the congeneric species, $P$. plancyi (Dai and Zhou, 2009), allele diversity of the loci isolated for $P$. hubeiensis was relatively low. However, no significant linkage disequilibrium $(\mathrm{P}<$ 0.01 ) was detected among these loci, and only two significant deviations from HWE were discovered at loci Pehu-11 and Pehu-12 (P<0.05). Results of MICRO-CHECKER tests showed that null alleles could be present at locus Pehu-12. These results showed that the microsatellite loci described here could meet the needs of exploring the mating mechanism, population genetic structure and other relevant genetic investigations of $P$. hubeiensis.

\section{ACKNOWLEDGMENTS}

Research supported by the Anhui Excellent Youth Foundation of Science and Technology (\#10040606Y18).

\section{REFERENCES}

Austin JD, Davila JA, Lougheed SC and Boag PT (2003). Genetic evidence for female-biased dispersal in the bullfrog, Rana catesbeiana (Ranidae). Mol. Ecol. 12: 3165-3172.

Belkhir K, Borsa P, Goudet J and Bonhomme F (1996). GENETIX: Logiciel sous Windows pour la Génétique de Population. Laboratoire Génome et Populations. CNRS UPR 9060, Université de Montpellier II, Montpellier.

Coulon A, Cosson JF, Morellet N, Angibault JM, et al. (2006). Dispersal is not female biased in a resource-defence mating ungulate, the European roe deer. Proc. Biol. Sci. 273: 341-348.

Dai JH and Zhou KY (2009). Development of microsatellite loci for Pelophylax plancyi and cross-amplification in other ranid species. Conserv. Genet. 10: 763-766.

Fei L and Ye CY (1982). The distributional characteristics of amphibian in Hubei Province, including description of a new frog. Acta Zool. Sin. 28: 293-301.

Foerster K, Delhey K, Johnsen A, Lifjeld JT, et al. (2003). Females increase offspring heterozygosity and fitness through extra-pair matings. Nature 425: 714-717.

Hamilton MB, Pincus EL, Di Fiore A and Fleischer RC (1999). Universal linker and ligation procedures for construction of genomic DNA libraries enriched for microsatellites. Biotechniques 27: 500-507.

Lataste F (1880). Batraciens et reptiles recueillis en Chine par M. V. Collin de Plancy. Bull. Soc. Zoo. France 5: 61-69.

Liu K, Wang F, Chen W, Tu L, et al. (2010). Rampant historical mitochondrial genome introgression between two species of green pond frogs, Pelophylax nigromaculatus and P. plancyi. BMC Evol. Biol. 10: 201. 
McDiarmid RW and Altig R (1999). Tadpoles: the Biology of Anuran Larvae. University of Chicago Press, Chicago.

Newman RA (1988). Genetic variation for larval anuran (Scaphiopus couchii) development time in an uncertain environment. Evolution 42: 763-773.

Okada Y (1931). Tailless Batrachians of the Japanese Empire. Nishigahara, Tokyo.

Pope CH (1929). Four new frogs from Fukien Province, China. Am. Mus. Novit. 352: 1-5.

Raymond M and Rousset F (1995). Genepop: population genetics software for exact tests and ecumenicism. J. Hered. 86: 248-249.

Sambrook J and Russell DW (2001). Molecular Cloning. 3rd edn. Cold Spring Harbor Laboratory Press, New York.

Uller T and Olsson M (2008). Multiple paternity in reptiles: patterns and processes. Mol. Ecol. 17: 2566-2580.

van Oosterhout C, Hutchinson WF, Wills DPM and Shipley P (2004). Micro-checker: software for identifying and correcting genotyping errors in microsatellite data. Mol. Ecol. Notes 4: 535-538.

Wilbur HM (1997). Experimental ecology of food webs: complex systems in temporary ponds. Ecology 78: 2279-2302. 